\title{
NATIONALISM, SUBVERSIVE HISTORY AND CITIZENSHIP: THE QUEST FOR IDENTITY IN THE POSTCOLONIAL NATION IN M.G. VASSANJI'S THE IN-BETWEEN WORLD OF VIKRAM LALL
}

\author{
JAMES ORAO \\ University of Nairobi \\ jorao@uonbi.ac.ke \\ ORCID: 0000-0002-8704-3286
}

\section{ABSTRACT}

One must write for one's age, so says Sartre, arguing that the writer needs to go beyond a passive reflection of his/her age to want to maintain it or change it (1988: 243). But there is no such thing as a passive reflection where history is concerned and the need for constant questioning of held or handed down beliefs, as propagated by the postmodern approaches, resituates the writer and his/her audience into newer and more dynamic definitions of and reflections on that age. This paper, by looking at M. G. Vassanji's kaleidoscopic constellation of characters, an other way to look at Kenya's history around those defining moments of the struggle for independence and thereafter in his novel The In-Between World of Vikram Lall (2005), seeks to discuss the notions of identity and especially how it is informed by nationalist movements. Vassanji, in all his books, has consistently attempted to situate the often-ignored Afro-Asian within the often ethnocentric African history. In this text, this attempt is placed within the backdrop of several histories and as such it reflects, not passively, but actively and questioningly and at certain points even subversively on what it means to be Kenyan.

KEYWORDS: identity, nationalism, history, African-Asian, Vassanji, subversion.

\section{INTRODUCTION: LITERATURE AS SUBVERSIVE HISTORY}

Novels arise out of the shortcomings of history (Gomez n.d.) and can be looked at as a deliberate critical and creative medium of producing as well as filling in gaps in officially sanctioned knowledge (Kahyana 2003: 98). And because of its ability to offer alternative takes on sanctioned myths and historical accounts, a novel can and does challenge both the private and the public versions of history: "[literature] embodies in word [...] the tensions, conflicts and contradictions at the heart of a community's being and becoming" (ibid.). And in so doing, a novel can and does offer sites for questioning officialdom, for questioning the self and for questioning the family myths and in effect for questioning identities.

Vassanji's take on the postcolonial history of the East African states has always been that of complex and multi-layered artefacts with competing narrations pitting racial and cultural minorities within the postcolonial nation and state entities (Siundu 2017: 1): his two earlier novels, The Gunny Sack (1989) 
and The Book of Secrets (1994) easily come to mind. Indeed, his works have been analyzed within such aspects as (im)migration, arrival and identity. Just to mention a few scholarly engagements with his works: Simatei (2011) notes the counter-nationalistic discourses inherent in the works but zeroes in on the enactment of the difference of the diasporic subject. He traces the histories of Asians in East Africa in Vassanji's No New Land (1991), The Book of Secrets (1996), The Gunny Sack (1989) and The In-between World of Vikram Lall (2003) concentrating more on the discourses of home. Kahyana (2003), likewise, focuses on the "postcolonial crisis of identity" and how this is narrated using a selection of East African Asian fiction and grounds his arguments on a selection of works of Dawood, Nazareth and Vassanji. Malak (1993) departing from what he refers to as "ambivalent affiliations" considers Vassanji's The Gunny Sack (1989), No New Land (1991) and Uhuru Street (1992) and notes the omnipresence of "cross references to episodes, events, and characters that appear in more than one work" (Malak 1993: 277), which to him suggest that certain private and/or private experiences and images have the power to emerge and reemerge indefinitely. These private and/or collective memories thus are seen as motivic in Vassanji's works. Siundu (2017) on the other hand looks at Vassanji's own deconstruction of history that makes him re-look at India and its historical significance on the identity of the South East Asian Diaspora. This paper is complementary to the foregoing scholarship: departing from the already stated constructions of the South East Asians in East Africa as a "buffer" community and as "in-betweeners" with a crisis of identity, this paper focuses primarily on the narrative strategies used to achieve the above, while also arguing that the strategies are moreover employed to deconstruct the prevailing discourses of the majority that seek to position the South East Asians within the "buffer" and "in-betweener" perceptions.

Vassanji's novel, The In-Between World of Vikram Lall (2005), seeks to unravel several myths of nationhood, recreate histories and situate the East African South Asians within the pre-independence movements and the postindependence machinations in Kenya's search for nationhood beyond the colonial determinacy. In the novel, Vassanji "revisits the ambivalent relationship of [East African-]Indians to Kenya's national history" and "demonstrates the Asian complex entanglement with Kenya's equally contested histories" (Simatei 2011: 63). He effectively situates the novel within a time of exclusionary and "potent brew of Kenyan politics, with its corruption, tribalism, and violent vendettas [that] made it impossible for the [East African]Asian minority to raise their voice" (Siundu 2017: 2). Because the minority lacks the political impetus of the majority, it has to contend with being marginal(ized) in the writing of historical accounts. Thus, the crafting of a counter-narrative from a minority position inescapably hits upon the resistance of majority-shored master narratives. For this reason, the only avenue open to any member of such a minority to partake of common history would be to tell 
his/her story from a personal point-of-view. In addition, the story would have to be woven in such a way that as many mainstream actors as possible are looped into his/her narrative.

The colonialists, as well as the African nationalists before and after independence, get sucked into the storytelling: this is a strategy that ensures that the minority located subject is at the same time complicit while countering established narratives, thus, ensuring that the narrator remains "sensitive to possible counters from the audience" (Bamberg 2004a: 363). The novel describes the lives of an East African South Asian family in Nakuru (within the Rift Valley and home to a large number of the white colonialists) during the state of emergency years and subsequently follows them to Nairobi (the capital city) during the post-independence euphoria with its accompanying upheavals. The back-and-forth narration weaves a constellation of relationships between the East African South Asian minorities and other 'Kenyans', providing a kaleidoscope of ties, friendships and betrayals - entanglements that in the end, point to the dynamics of the nationhood of Kenya, and the problematic construction of its post-colonial identity.

History, understood as "the sum reservoir of past experiences" (Mazrui \& Mhande 1990: 47) is not all the same and "the past can be idealized to imbue peoples with a sense of their identity, or debased to create self-doubt and despair" (Mazrui \& Mhande 1990: 50). To echo Rushdie (2010: 13), does literature seek to do more than describe, or can it open more doors? While not laying claim to historical accuracy, this novel, nevertheless, seeks to open more doors: it seeks to break a silence; to give voice to a people neglected in historical accounts of Kenya's nationalism and nationhood; to present a "plausible 'truth', while based on [not so] fictitious characters and events" (Black 2000: 87); it is "an elliptical, unofficial, unorthodox history" "interjecting fictional fabrications with historical facts and figures" (Malak 1993: 277). Indeed, it is radical and contrary to the position occupied by the early independent East African Asian intellectuals who, not wanting to draw undue attention to their then very precarious belonging, shied away from their gods and their languages, their traditions and personal lives and "seemed largely to prefer the safety of the universal, the minimal, the casual observation" (Siundu 2017: 3). As a counternarrative of the positions and positionings of the South Asian individual and community in East Africa, the novel at once gives voice to the children and grandchildren of those indentured South Asians who, "as part of the labor mobility within the British empire" (Malak 1993: 277), built the MombasaKisumu railway for the (in)famous 'Lunatic Express', while at the same time challenging their sometimes self-imposed non-belonging and ambivalence, with feet planted in both countries, ready to flee, when one place gets too hot (Vassanji 2005: 342). Further, in this counter narration vein, it sets itself against the "truth-discourses" (Black 2000: 87) of history and belonging by providing an other plausible history; effectively partaking in the discourse on Kenyan-ness. It 
seeks to "give the lie to official facts" (Rushdie 2010: 14) by re-placing the members of the South Asian community back into those portraits of a nation and myths of nation-building from which the hegemonic master narratives had effectively erased them.

Based on the Bakhtinian argument that "an individual speaker's utterance is not just coming from an isolated, decontextualized voice" (Hermans 2004: 300) but rather manifests various cultures and discourses in which it participates, this novel has effectively "been put in the position of telling truths that the official discourses of [Kenyan] history cannot speak" (Black 2000: 92). The "momentous histories of [the Kenyan nation state] are deconstructed through private experiences, memories and narrative strategies" (Mohapatra 2006: 3) that seem to leave none of the cornerstone historical figures of Kenyan nationalism untouched. By so doing, the novel brings to disrepute aspects of history while at the same time foregrounding questions of identity, belonging and "ambivalent affiliations" (Malak 1993: 277) of the East African South Asian nation within the Kenyan state.

By taking a subversive stance against official historical discourses and by purporting to recount tales about the various stances in the search for Kenya's nationhood the novel becomes political (questions of identity and belonging are inherently political); it posits questions that have been ignored in the officially propagated accounts by allowing voices hitherto silenced to come forth and tangle the neat accounts that make up official history. The In-Between World of Vikram Lall (2005) seeks, in this subversive vein, to

re-tell the Asian experience as versions, not of official history of the nation, which is hegemonic and exclusionary, but of those dynamic, multidirectional, and revolutionary histories of the national people. (Simatei 2011: 57)

By allowing these voices, the novel, thus, offers a forum through which tales of belonging and identity of the minority other can intermingle with the already sanctioned voices of the majority; if not to challenge these sanctioned voices, then to expand the repertoire of identities that make up the fabric of the nationhood of Kenya:

Indeed, the very act of writing the Asian presence in East Africa is itself an attempt to uncover connections to histories of resistance that get suppressed when the stereotype of Asians as collaborators of colonialism is amplified within the official discourse of nation building. (ibid.)

Lall's narrative helps one understand the unique manner in which the South Asians got situated within the social relations of class, race and the other axes of differentiation in colonial and post-colonial Kenya (see Mohapatra 2006: 3). The historical accounts of resistance of the South Asian community in East Africa do not only get suppressed by the stereotype of the 'Asian' as a colonial collaborator, "merciless exploiters of the Africans, and a monolithic trading 
community" as "Jews of Africa" (Kahyana 2003: 101) and as "parasitic" (Mohapatra 2006: 5), but also by the lack of their voice to compete with the myriad of other voices in claiming a place for themselves within the collective narrative of national belonging. Vikram Lall's kaleidoscopic narration in this novel is, thus, "a deliberate endeavor at contextualizing an individual's destiny within that of a family's, an ethnic community's, [and] a nation's" (Malak 1993: 277). Lall, located as he is within the "cross-currents of history and myth" (Mohapatra 2006: 10), through his sometimes outrageous - especially in the surprising entanglements of the perceived 'outsiders' with the politically powerful particularly during momentous junctures in the history of the nation - narration, negotiates communal and individual identities, and with it the history and identity of the nation-state before and after liberation from colonialism: "He explores the past, constructs genealogies and traces the complex formations of the sites of subjectivity" (ibid.) through associations, betrayals and commissions. Indeed, Lall's story fluidly moves and encompasses the whole spectrum of - both cornerstone and minor - players in the nationalist identity construction project, sometimes in an accusing tone, other times in a simple narrative of the state of affairs in the pre- and post-independence nation. The historical portrait of a nation that emerges in his narration renders the extant historical accounts contentious.

\section{IDENTITY: 'SELF-MARKING' AND SELF-MAKING}

To controvert history and re-write himself, his family and, thus, his South Asian community into the national narrative means to write against power and hegemony; it means to find an entry point into the streams of narratives that are designed to locate and affirm various identities that claim belonging into the Kenyan nation and present a compelling point-of-view from where to represent himself. Identity in this context is understood as a matter of telling stories: it is

primarily, a matter of stories persons tell others about themselves, plus stories others tell those persons and/or other stories in which those persons are included. (Whitebrook 2001: 4)

Identity is, consequently, a subjective narration of the self and others; a discursive exercise entailing "placing the self in the public sphere" (ibid.). And as Vikram Lall, the protagonist in this novel, says in the prologue, "[...] I simply crave to tell my story" (Vassanji 2005: 1). His statement, which is an assertion of a desire to add his voice to those narrating Kenya's nationhood and a plea to be seen as a member of the larger Kenyan nation, also serves as a marker of his intention to serve a counter-narrative to the existing narratives of nationhood. The simple statement summarizes the underlying question of identity in the novel: no longer content with being an object of identity discourses, Lall chooses 
to reject such deterministic trends of the master narratives that would see him and his people positioned on the fringes of national history and, as a result also denied a sense of belonging, and adopts a more agentive stance of selfreflection and self-criticism (see Bamberg 2004b: 223-224). His seemingly personal story is, of course, as revealed in the many pages of the book, not just his story, but also the history of a people, a country and a nation: they are, as Vassanji notes, stories that have never been told and must be told or they will soon be forgotten (Desai 2011: 190-191) thereby removing any possibility of them being part of the repertoire of historical accounts. In confronting the existing narratives regarding his community, Lall's story weaves in and out, encapsulating the historical accounts as well as stories and myths of diverse peoples, with the result that an identity of a nation emerges, only to be suspended, revised and retold.

Having been positioned as the other in the national narrative, Lall's claim to and search for belonging is, however, scuttled by the historical trajectories of the South Asian community in the country:

Several trajectories of relating Indian experience to Kenya's history emerge: First, Indians are in Kenya as subjects of the expansive British Empire. Vikram's grandfather like other Indians came from British India to work on the Uganda railway. In the colonial Kenya they create a buffer zone between "white privilege and black misery". But several years later, African nationalism throws their safe haven into disarray as the British Empire collapses. (Simatei 2011: 63)

That the indentured South Asians, just like the black Africans, were colonial subjects is hardly the issue where identity, belonging and historical situation are concerned. These issues get complicated, in the first instance, by the colonial power matrix that disenfranchised both groups equally, by creating a discursive constellation of power, race and ethnicity that placed the South Asian community below the colonizer but above the black African, but with an assurance of being more accepted into the greater British empire, an acceptance which the black African did not enjoy. Racially, culturally and politically the South Asian community is excluded and relegated to the fringes of the discursive entanglements between the colonialists and the African nationalists. As such, a framework for identity politics is created, where for the South Asian, Kenya becomes - as for the colonizers - a temporary sojourn away from home in the colonial centre, England. The colonial master narratives of the South Asian being more equal than the African, therefore, need to be dismantled and retold so that perceived contradictions on the way to the construction of a sense of belonging can be dispensed with.

Lall's story is, therefore, his attempt to not only position himself, and in effect, his people, in the narrative of Kenya's nationhood, but also to try to mitigate against the adversity of the historical accounts against his people. Because "narratives order characters in space and time" (Bamberg 2004a: 354) 
Lall walks the thin line of countering existing narratives against his South Asian community while also admitting complicity with the hegemonic narratives of nationhood. Through a spatio-temporal self-positioning, he tries to affirm his Kenyanness:

We have been Africans for three generations, not counting my own children. Family legend has it that one of the rails on the railway line just outside the Nakuru station has engraved upon it my paternal grandfather's name, Anand Lal Peshawari, in Punjabi script - and many another rail of the line has inscribed upon it the name and birthplace of an Indian labourer. (Vassanji 2005: 16)

With this strategy, Lall is - on the one hand - positioning his family within the public sphere, affirming first their Africanness, then scripting them into the nation-building narrative of Kenya; he is more than "a Panjabi protagonist [paying] tribute to the community that built the railway" (Desai 2011: 191). India (where the prevalent hegemonic narrative tries to place him, his family and his people) remains a "fantasyland", a place where "my father proudly Kenyan, hopelessly [...] colonial - went to [...] once, and brought back my mother" (Vassanji 2005: 21). The othering narrative placing them in India and as such denying their unique Kenyanness is repudiated by his narrative affirming his Kenyan identity: "I knew of no world outside my Nakuru, this home, this backyard, the shopping centre, the school [...]" (ibid.: 54). Lall recognizes the fact that "[q]uestions of where you are from are [...] most often about who you are" (Zaidi 2020: 140). Apart from repudiating the othering attempts that seek to place him in India, his proclamation of Nakuru being his home also seeks to locate him away from the racially or ethnically coded fringes - according to the colonial ordnances of the day - and, thus, marginal or too central that it is considered colonial privilege; both locations which would effectively lock him out of the nationalist discourses on belonging: in essence, he locates himself among the 'ordinary' Kenyans, who do not need to reaffirm their belonging. On the other hand, the railway in postcolonial Kenya embodies a variety of significant symbols: it is, at once, "a symbol of colonial conquest and exploitation of Kenya's entry into modernity" (thereby situating the South Asian community in East Africa within the loathed colonial enterprise), and "of [South Asian] affiliation to the land" (thereby cementing their identification with the nationhood) (Simatei 2011: 64); it is both a bane and boon in the discourses surrounding the identity of the South Asian in Kenya. But as Zaidi (2020: 141) observes, lives, and thus identities, are contained in the witnessing and recognition, which is exactly what Lall tries to achieve with his narrative in which he positions his family and his community within the modernizing endeavour that followed colonialism.

And in a country struggling to find its nationhood, identity in whichever form it may take becomes foremost; its documentation is an act of invention, intervention and narration. The cacophony of voices raised in contesting 
storytelling of the straggling nation drowns out the voices of the minority groups, which did not have a Jomo Kenyatta as rallying figure-head and blackness as a badge of belonging - the names of Pio Gama Pinto and Makhan Singh, who would testify to the contribution of the so-called 'outsiders' in the fight for the nationhood are conveniently drowned out in this discordance. Indeed, Lall - as has been noted above- chooses to concentrate on the individual and familial connection to the nation in his bid to counter the discourses of disenfranchisement. In his counter-narrative he chooses to exhibit complicity with the master narrative of national liberation movement and claims his space right there with the purported Mau Mau movement in the form of an oath Njoroge administers to him: "All those secrets I have told you, you will not tell them to anybody? [...] I will not tell anybody. [...] You must take an oath. I will take an oath" (Vassanji 2005: 104). Beyond the childhood antics of the young Lall and his friend Njoroge, Lall's narration further weaves a web that brings his own family right into collusion with the dreaded -by both the colonialists and their collaborator home guards alike - nationalist Mau Mau movement: he writes his uncle, Mahesh, into the Mau Mau narrative by crafting him as an underground collaborator of the nationalist movement, who went out of his way, risking his relationships with his immediate family which collaborated with the colonialists, as seen in Lall's father being part of security patrol against Mau Mau - to supply provisions, medication and even a pistol (stolen from Lall's father) to the outlawed freedom fighters. Lall's strategy, here, is to contest the sanctioned historical accounts that seek to portray the East African South Asian community as apolitical fence-sitters in the fight for independence, who did not invest in the struggle for nationhood and may thus not partake of the Kenyan identity by crafting Mahesh as a "counter character" (Bamberg 2004a: 362): he gives him a subordinate role, which in the grand scheme of his narration, however, sneaks his family and people into the nationalist mythology and, consequently, works towards cementing their belonging into the general fabric of nationhood.

Because the foundation of Kenyan nationhood is built on myths and stories of these struggles, Lall's story exposes a weakness in the construction of identity through narration. The official storytellers of the budding nation forgot a very important aspect of identity: that the identity of a dynamic entity, as the upcoming nation was then, could only be fluid and mutable. This mutability is shown in the novel as the narration transitions from the pre-independence Mau Mau battles against the colonialists to the post-independence period with its attendant new power matrix. Those that thought they belonged find themselves questioning their own belonging and in effect the nationhood - the identity of the newly independent state. Njoroge, who had impressed upon Lall the messianic character of Kenyatta (Vassanji 2005: 53), later turns around and warns him to use a long spoon while dining with the devil. While during the emergency it was the privileged classes, the Europeans and the South Asians, 
who called Kenyatta daitya, in post-independent Kenya it is the former devotee Njoroge who sees in him the Devil. On the other hand, Lall - formerly of the buffer community of the South Asians - seems to have transcended the power matrices and found himself in the inner circle. The professed level of complicity at this point in Lall's counter-narrative begs disbelief: Not only is Lall's story and its accuracy, or maybe his interpretation of events, put into disrepute especially as he falls out with his old childhood friend Njoroge- the whole narrative of the nationalist movement -its flagbearers and its goals and achievements - and with it, the morality of the newly independent nation is also in effect questioned. His acquiescence to complicity, in this case, seems to have been a narrative strategy of demolishing the nationalist narrative from within.

But it is not only the nationhood that is portrayed as in flux. The very identity as Africans and Kenyans that Lall tries to narrate for himself and his people keeps changing; sometimes as self-positioning, sometimes as an act of othering by entitled Kenyans. As Lall himself says, especially of his parents' generation: "they were too inconsistent and confused about where they stood and who they were, even as they called themselves Kenyans" (ibid.: 173); they exhibit a disavowal and, at the same time, an inherent need for identification with the newly independent state. This state of flux seems to increase with the post-independent moderation of the once inviolable distinctions along racial lines. While during the emergency period Lall and his family gladly proclaimed their African roots and, thereby, their Kenyan identity, in the newly independent Kenya they simultaneously affirm and repudiate their long fought for identity: "Get this in your head Deepa, he is an African, Papa said. He is not us. [...] What do you mean? What's wrong with an African? I am an African. What hypocrisy!" (ibid.: 206) The relationship between the South Asian community and their chosen home becomes "a relationship straining for definition" (ibid.: 232), as witnessed by the exchange between Njoroge and Mrs Lall:

\footnotetext{
At least let me have a normal family, where I can see my grandchildren grow up as Indians, as Hindus. I had dreams too, of children and grandchildren - whom I can [...] bring up in our ways. I have nothing against Africans. But we are different. You are a brother to my son and daughter, you are their best friend. But a husband for Deepa - no, Njoroge. (ibid.: 248)
}

In a situation already strained, such 'puritanical policing' (Desai 2011: 188) and an "obsession with 'pure' blood and genetic segregation" (Zaidi 2020: 100) by a conservative generation can only further complicate matters relating to identity and belonging. As Simatei (2011: 58) points out regarding the older generation, "its essentialist and regressive self-portrayal as a guest community valuing myths of cultural purity, [...], complicates its entry into the emerging 
postcolonial nation". Zaidi makes the same observation regarding the essentialist positions of identity in India after the partition:

I used to wonder why it mattered so much to politicians that people don't marry for love. [...] People cross borders, give up class and caste privilege for love. This is terrifying for politicians because it can make people reexamine identities. (Zaidi 2020: 107)

Lall does not spare his own family and community in his counternarratives. Relationships become convoluted and professed identities come into question. Lall, his family and, consequently, the wider South Asian community are shown to be complicit in their own marginalization and not belonging. And thus, the question that Vassanji seems to posit here is: in how many ways can identity be constructed and is there a possibility of redemption?

Lall's counter-narrative strategies unmask identity as flawed: "incomplete, shaky, dying the moment it has been born" (Bauman 1994: 138), susceptible to deconstruction and reconstruction. Narratives are supposed to reveal the speaker's identity (see Bamberg 2004a: 358) and even as Lall struggles to undermine the prevailing master narratives, he realizes that the dynamics of history, as well as political and cultural power matrices within the post-colonial state, do not provide him with an adequate foothold to position himself; he cannot stand still long enough to reflect and find himself, "because there is no place to stand still on. Every 'now' melts away and disappears, no 'now' can be expected to last" (Bauman 1994: 138). Transience that characterizes the new political state of the nation is brought to the fore as follows: First, the re-union of Njoroge, Deepa and Lall which would have helped temper the puritanical and fundamentalist ideals of Lall's mother and maybe forge a hybrid identity through marriage is thwarted; second, Lall's forays into the inner sanctums of the new power matrices which would have built up into new relationships within the new nation-state are shown to be temporary. The failure of individual persons to work through possible alternate and/or new ways of belonging is mirrored on the larger state construct's failure to allow for more diversity in its nationhood.

Lall's construction of identity through the literal narration of stories ends in self-doubt; as it should. Identity abhors permanence. The in-between world seems to be the only place left:

Here I was, a young Asian graduate in an African country, with neither the prestige of whiteness or Europeanness behind me, nor the influence and numbers of a local tribe to back me, but carrying instead the stigma from a generalized recent memory of an exclusive race of brown "Shylocks" who had collaborated with the colonizers. [...] Black chauvinism and reverse racism were the order of the day against Asians. (Vassanji 2005: 276)

Of course, this in-between world is hardly a place of his own choosing; he has been placed there by competing discourses: first, the colonial discourses 
that saw in him neither the native African nor the white colonialist and used him as a buffer between the two, and second, by the post-independence chauvinism that saw in him a caricature to be used and tolerated. The discursive constellations upon which he and his people were perceived, and which complicated their project of identity construction as Kenyans were based on

(alleged) racial and social exclusiveness; [...] (alleged) economic exploitation and domination of Africans, and [...] (alleged) identification and collaboration with the British [...] empire builder. (Kahyana 2003: 98)

The South Asian community of Kenya are thus seen as a body politic that deliberately sets itself out as the other and lacks "communitarian citizenship" (ibid.: 99); the libertarian self-interest favoured by the South Asian community and the communitarian self-interest upon which many African nations are built are, according to Kahyana (ibid.: 100), mutually exclusive. Lall's narrative is trying to break from this discursive strait-jacket. He seems to say: to tell his story is to look the postcolonial nation full in the face and lay bare the inherently intimate betrayals of "neighbour turning on neighbour [and] employees turning on employers" (Zaidi 2020: 100) that accompanied the nationalist movement frenzy in the colonial and early post-colonial period.

\section{NATIONALISM AS A PROCESS IN THE CONSTRUCTION OF IDENTITY}

Vikram Lall's story effectively engages in a debate over the reality of what makes up Kenya's identity and nationhood. The presented discourses on the nationalist movements before and after independence present an assortment of character constellations fraught with betrayals: they question each other's roles, commitments, belonging and, in essence, identities. The barriers of ethnicity, class and prestige are presented as both inviolable and breakable (Vassanji 2005: 9). But this is a political act on the author's side; a defiant giving of voice to a silenced section of society by allowing Lall to spin his counter-narratives against the prevalent narratives and, accordingly, writing them into the discursive relationships of nationalism and nationhood.

But Vassanji knows that the memory that makes up the historical recollections is as fallible as the sanitized myths that make up official accounts of history. That is why Vikram Lall's accounts and recollections get disrupted and sometimes his perceived memories of events questioned and severally brought into disrepute: was his childhood epitome of gentility, Mwangi, as innocent of Mau Mau involvement as he imagined? Mwangi's own grandson, Njoroge, disavows him of this illusion by informing him, much later in life, that Mwangi did, in fact, administer oaths to Mau Mau movement supporters; Kihika, the epitome of Mau Mau dread in his childhood later resurfaces carrying the centrepiece of colonial morality - the bible; the feared colonial 
Sergeant Soames - whose name spread fear among the Mau Mau collaborators - resurfaces as a still feared Inspector in the Special Branch in independent Kenya - again charged with hunting down the detractors of the newly independent state-, as does corporal Boniface, now a Major in the GSU (ibid.: 328). These inconsistencies in biographical progressions of the key players in Lall's narration point not only to the fallibility of memory but also to a necessity of reevaluation of the various players and their roles in the composite narrative that became the Kenyan nation.

Rushdie sums up this fallibility in the narration thus:

$[\mathrm{H}]$ uman beings do not perceive things whole; we are not gods but wounded creatures, cracked lenses, capable only of fractured perceptions. Partial beings, in all senses of that phrase. Meaning is a shaky edifice we build out of scraps, dogmas, childhood injuries, newspaper articles, chance remarks, old films, small victories, people hated, people loved [...]. (Rushdie 2010: 12)

This partiality also results in an incompleteness in the search for identity. As shaky and fragmented as it is portrayed here, one can only surmise that whatever identity is constructed through narration, may not hold out in a retelling and/or rewriting. But this search for meaning on a personal level translates to the search for meaning on a national level; and the questioning of the personally held stories, myths and beliefs equally apply to the national construct: if those finding themselves within the borders of the newly emerging nation could not pin down an acceptable identity for themselves, then the very nature of that emerging nationhood must also be in question. A nation means a people. What kind of a nation comes out of Lall's story? Lall foregrounds the failed nationalist movement by only being able to tell his story while in exile. The position spatially outside the location of his identity contestation allows him to fearlessly present a counter-narrative that subverts official history, but also to undermine the post-colonial nationalist identity the nation-state seems to claim for itself. And the fact that he is in exile as he tells his story, means that he is done with his complicity with the Kenyan master narratives of identity and nationalism.

Nationalism does involve a certain level of repression of a group of people in order to champion the rights and identity of a majority. The process of claiming nationhood means that borders, both internal and external, have to be claimed, contested and defended; hegemony and power have to be projected; peoples are in effect included or excluded; a sense of belonging is created or affirmed, while others are repudiated. It is, therefore, impossible to delink nationalism (as the search for a sense of national identity especially to the exclusion or detriment of the interests of others) from the construction of or search for personal identity. As Prof. Yash Pal Ghai - a Kenyan constitutional scholar of international repute - noted in his keynote address at the 2016 Samosa Festival colloquium at the University of Nairobi, the process of making 
a constitution is a nationalist endeavour that must also be looked at as another process in the construction of national, communal and personal identity. ${ }^{1}$ This constitutionally sanctioned sense of belonging, however, is a slave to the various voices raised in their own narrations to claim a place in the nation; the cacophony of which drowns minority voices. Lall, and even Vassanji, blame the South Asians in post-independence Africa of "a minoritarian identity":

[o]ne of the dilemmas of post-independence Asians in East Africa, was 'how to insist on one's Kenyanness or Ugandanness without letting go of long held cultural/religious/ethnic identities?'(Desai 2011: 188)

Indeed, speaking about Muslims in India, but a statement that equally applies to the South Asian community in Kenya, Vassanji says that minorities in majorly homogenous ethnic/religious nations should assert their essential and primary identities, "shouting it from the rooftops and from their guts", instead of falling "into the trap of allowing themselves to be seen as minority and as outsiders" (ibid.), accepting an ascribed identity that denies their roles in the general nationalist struggles and the struggles for nationhood. Lall's "I simply crave to tell my story" is such an assertion and proclamation of personal, communal and national identity.

Questions on identity have always been problematic and the people residing within the borders of a nation-state cannot and should not be regarded as a "unified interpretive community" (Black 2000: 92) of any propagated official history, especially where the said history lacks inclusivity. Failure of history to be unifying of all the peoples in a nation-state inevitably leads to failure to develop an all-inclusive sense of nationhood. And so, while the colonial Kenya of the emergency period could not pretend to lay a claim to nationhood, the post-colonial Kenya wants to portray an image of nationhood; and succeeds to a point. But at the point where the personal identity and sense of belonging become contested and in dire need of renegotiation, the country also begins to show cracks in its nationhood. It is the failure of the country itself to define its nationhood and thus provide footing for the others to find their identities.

This failure manifests itself in the failure of the nationalist movement preindependence. Lall paints a picture of a nationalist movement that had all kinds of peoples in its ranks, but which at the end of the struggle decided to spurn these collaborators and perpetuate the idea of it belonging to only one group the black Africans. The socialist-leaning Mahesh (Lall's uncle), the socialist-

\footnotetext{
1'Kenya's constitution is about identity in a number of ways. First and foremost, it is about defining our identity as a people. This is stated upfront - in the preamble - where, in the name of the people, the constitution says that we are 'Proud of our ethnic, cultural and religious diversity, and determined to live in peace and unity as one indivisible sovereign nation'. It commits us to 'nurturing and protecting the well-being of individual, the family, communities and the nation'".
} 
oriented Indian High Commissioner and even Deepa (Lall's sister), who hides Njoroge under her bed during a police operation to flush out Mau Mau sympathizers, are not considered heroes of the nationalist movement and cause, because it is convenient for the post-independent nationalists to write them out of history.

While the problem of nationalism and nationhood in pre-independence Kenya and, as a result, the problem of constructing personal and collective identities stemmed from the fact that self-determination is impossible in a colonized state, Lall's story shows that it was the matter of ego and chauvinism that shattered the search for nationhood post-independence. The starkly defined ethnic, class and prestige boundaries that were set by the colonizers reduced the colonized subjects, both of African and South Asian origins, to selfish peoples who could only advance selfish agendas within boundaries predetermined by the colonizers; meaning that their sense of identity was also predetermined by the experience of colonialism. The semantics of nationhood in the colony were restricted to ethnic groupings, with the empire reserving the supremacy in the hierarchy. Undermining this colonial semantic of nationhood was the impetus of the nationalist movement in pre-independence Kenya; an endeavour that Lall's story portrays to have been later subverted by ethnic chauvinism in the post-colonial state.

Where in the pre-independence constellation the colonizers determined the boundaries of belonging, the post-independence Kenya brought forth new constellations that sometimes defied the old order and at some other times starkly reaffirmed them. And as the colonial Europeans and colonial-minded South Asians were abandoning the country at independence, the newly independent black Africans inherited the chauvinistic, racist and othering tendencies of their former colonizers. The remaining South Asians found themselves in the same position as before; neither belonging within nor without, as Lall puts it:

We Asians were special: we were brown, we were few and frightened and caricatured, and we could be threatened with deportation as aliens even if we had been in the country since the time of Vasco da Gama and before some of the African people had even arrived in the land. (Vassanji 2005: 330)

These "few, frightened and caricatured" people, however, are crafted by Lall's counter-narrative as the counter characters in the master narratives defining Kenyan nationhood. Through them, Lall succeeds in reorienting his listeners to an alternative sequence of events that casts the minority community in a less fringe location. Furthermore, because his is a personal story, it is a story that is not open to public repudiation because it is not anyone else's to tell but his. He uses this caveat to spin his narrative, albeit in complicity with the master narratives, without fear that anyone might question his version of events. Complicity here means how certain aspects of the dominant stories are 
left intact, while others are reshaped and reconfigured. A complicitous counter narrator, consequently, does not stray far outside the dominating framework of the master narrative but works with components and parts of the existent frame to undermine these from within (see Bamberg 2004a: 363).

The politics of belonging was driven by majoritarian sentiments after independence. In a pre-independence constellation that saw the Europeans as the oppressors and the black Kenyans as the oppressed, the South Asian community was positioned somewhere in the middle. They were "considered [...] provisional and partial citizen[s] whose citizen status could be erased" (Kahyana 2003: 100) as was witnessed in Uganda in 1972:

One reason to explain this provisionality of the Asians' citizenship is that some Asians
did not fully identify themselves with the post-colonial East African nation-states, for
they either did not apply for Ugandan, Kenyan and Tanzanian citizenship, choosing to
remain British passport holders, or if they did, they still identified themselves not as
Ugandans, Kenyans and Tanzanians, but as Goans, Pathans and Indians despite the fact
that the passports they were holding were Ugandan not Goan, Kenyan not Pathan, and
Tanzanian not Indian. (ibid.)

While the colonial power matrix encouraged the in-between world of the South Asian community in East Africa, the post-colonial power matrix, on the other hand, condemned them for their ingratitude and "lack of commitment to the destiny of Africa" (Kahyana 2003: 100), while accentuating their minority status to destabilize their sense of belonging. The politics and the discursive constellations of colonialism that had ensured that they belonged to neither end of the spectrum; neither to the higher hierarchy of the white colonizers nor to the low-end cadre of the black colonized (see ibid.: 101) seemed to have carried over into the new post-colonial power matrix. But this was not for lack of involvement by the South Asian community at either end of the spectrum, as witnessed by the Home Guard Patrols that Mr. Lall undertakes in Nakuru or by Mahesh collaborating with the Mau Mau movement. Indeed, Lall's narrative seems to disavow

the perception that [South Asians] do not share, [...], the experience of colonial oppression and the history of decolonization, twin events that provide defining moments in the construction of nationhood. (Simatei 2011: 57)

Patriotism does not guarantee belonging, as Mahesh witnesses. And if ethnic and class chauvinism guaranteed a sense of belonging and provided a sense of identity to a select few, then neither did it definitely support a sense of national community nor did it help in shoring up the fledgling nationalism which would have borne the much sought-after nationhood. For the South Asian community, Kenyanness is thus not so much the question of contribution to the struggle nor the commitment to the location of the nation on the international agenda, as Mahesh tries to do; ancestry, too, seems to have been 
relegated from the equation of identity as pure ethnic chauvinism of the majority decides the discursive trend. To speak against the nation-state's neat nationalist narrative is to challenge its uniform presentation of nationhood. Lall's story is thus a subversive exercise against the seemingly coherent narrative of Kenya's nationhood and should be read as such.

\section{CONCLUSION: A WRITER'S PEOPLE}

So, if, to argue with Sartre further, to write for one's age means to reflect aggressively with the intention to change (Sartre 1988: 243), then for Vassanji, the question is: for which age did he write this novel The In-Between World of Vikram Lall? If a novel is taken to be an archival work, but one that redirects the gaze to the 'dark side' of history, then Vikram Lall's narration is meant to enrich the version of archived materials; an enrichment that at the same time questions officially sanctioned lore. Vassanji, like any other writer, "had to think about ways of looking and how [these ways of looking could] alter the configuration of the world" (Naipaul 2007: 2), and recast the sanctioned myths of nationalism and identity in ways that give voice to those either denied it or too timid to shout loud enough to be heard beyond the cacophony of competing nationalist voices.

The intellectual class and the political class being natural enemies, the process of claiming and reclaiming never really stops, as Rushdie succinctly puts it:

So it is clear that redescribing a world is the necessary first step towards changing it. And
particularly at times when the State takes reality into its own hands, and sets about
distorting it, altering the past to fits its present needs, then the making of alternative
realities of art, including the novel of memory, becomes politicized. [...] Writers and
politicians are natural rivals. Both groups try to make the world in their own images; they
fight for the same territory. And the novel is one way of denying the official, politician's
version of the truth. (Rushdie 2010:14)

Lall is not denying any official account, nor does he claim a more infallible version; he tells his story so that his story can be one of the many possible stories that defined and define Kenyan nationhood. "[...] the writer's task is, [therefore,] to invent -or reinvent- reality, [...] to tell or retell the [history]" (Black 2000: 92). Black calls this "a decentered history" (ibid.: 94), meaning that literature does not try to distort the official versions of history but illuminate it by incorporating the parts that might have been left out in the official lore.

In a nation still in search of its nationhood, the currency of storytelling goes beyond any one age. And if the world was created by the word, then Kenyan identity and nationhood and the construction of belonging within it can only be realized by telling the many different stories of those that call it home. 


\section{BIBLIOGRAPHY}

BAMBERG, M. (2004a), «Considering counter narratives», in Considering counter narratives: Narrating, resisting, making sense, Bamberg, M. \& Andrews, M. (eds.), Amsterdam, John Benjamins, 351-371.

BAMBERG, M. (2004b), «Narrative Discourse and Identities», in Narratology beyond Literary Criticism Mediality, Disciplinarity, Meister, J. C. et al. (eds.), Berlin-New York, Walter de Gruyter, 213-237.

BAMBERG, M. \& ANDREWS, M. (eds.) (2004), Considering counter narratives: Narrating, resisting, making sense, Amsterdam, John Benjamins.

BAUMAN, Z. (1994), «Desert spectacular», in The Flaneur, Keith Tester (ed.), LondonNew York, Routledge, 138-157.

BLACK, J. (2000), «Literature as Secret History», in Literatur im Zeitalter der Globalisierung, Manfred Schmeling et al. (eds.), Würzburg, Königshausen \& Neumann, 83-97.

GóMEZ, C. 'Novels Arise Out of the Shortcomings of History': An Interview with Juan Gabriel Vásquez. Interview Series, the Poetry and Literature Center at the Library of Congress. Washington: Library of Congress, 20 June 2016 [Access date: 27/09/2018]. Available at: <https://blogs.loc.gov/international-collections/2016/06/aninterview-with-award-winning-novelist-juan-gabriel-vsquez/>.

DESAI, G. (2011), «'Ambiguity is the driving force or the nuclear reaction behind my creativity': An E-conversation with M. G. Vassanji», Research in African Literatures, 42(3), 187-197.

GHAI, Y. P., «The law aims to give every Kenyan sense of belonging» [online]. Nairobi: 2016 [Accessed date: 03/12/2020]. Available at: <https://katibainstitute.org/thelaw-aims-to-give-every-kenyan-sense-of-belonging/>.

HeRmans, H. J. M. (2004), «Introduction: The Dialogical Self in a Global and Digital Age», Identity: An International Journal of Theory and Research, 4(4), 297-320.

IYER, N. (2011), «No Place to Call Home: Citizenship and Belonging in M. G. Vassanji's The In-Between World of Vikram Lall», in Negotiating Afropolitanism. Essays on Borders and Spaces in Contemporary African Literature and Folklore, Wawrzinek, J. \& Makokha, J. K. S. (eds.), Amsterdam, Brill Rodopi, 204-214.

KAHYANA, D. (2003), «Narrating National Identity. Fiction, Citizenship and the Asian Experience in East Africa», Africa Development / Afrique et Développement, 28(1/2), 97-111.

MALAK, A. (1993), «Ambivalent Affiliations and the Postcolonial Condition: The Fiction of M. G. Vassanji», World Literature Today, 67/2, 277-282.

MAZRUI, A. \& MHANDE, L. (1990), «The Historical Imperative in African Activist Literature», Ufahamu: A Journal of African Studies, 18(2), 47-58.

MeISTER, J. C. et al. (eds.) (2004), Narratology beyond Literary Criticism Mediality, Disciplinarity, Berlin-New York, Walter de Gruyter.

NAIPAUL, V. S. (2007), A Writer's People. Ways of Looking and Feeling, London, Picador.

RUSHDIE, S. (2010), Imaginary Homelands, London, Vintage Books.

SARTRE, J. P. (1988), "What is Literature?" And Other Essays, Cambridge, Harvard University Press.

SCHMELING, M., SCHMITZ-EMANS, M. \& WALSTRA, K. (eds.) (2000), Literatur im Zeitalter der Globalisierung, Würzburg, Königshausen \& Neumann. 
SimAteI, P. (2011), «Diasporic Memories and National Histories in East African Asian Writing», Research in African Literatures, 42/3, 56-67.

SIUNDU, G. (2017), «Vassanji's disquiet with history in A Place Within», Journal of African Cultural Studies, 30(1), 6-19.

TESTER, K. (ed.) (1994), The Flaneur, London-New York, Routledge.

VASSANJI, M. G. (2005), The In-Between World of Vikram Lall, Edinburgh, Canongate Books.

WAWRZINEK, J. \& MAKOKHA, J. K. S. (eds.) (2011), Negotiating Afropolitanism. Essays on Borders and Spaces in Contemporary African Literature and Folklore, Amsterdam, Brill Rodopi.

WhitebrooK, M. (2001), Identity, Narrative and Politics, London, Routledge.

ZAIDI, A. (2020), Bread, Cement, Cactus. A Memoir of Belonging and Dislocation, Cambridge, CUP. 